\title{
THE EFFECT OF XYLOPIA AETHIOPICA (UDA) ON INTRAOCULAR PRESSURE
}

\author{
BY \\ *UZODIKE, E. B. AND ONUOHA, I. N. \\ DEPARTMENT OF OPTOMETRY \\ ABIA STATE UNIVERSITY, UTURU, ABIA STATE \\ Email: ebeluzo@yahoo.com \\ *Corresponding author
}

\begin{abstract}
Xylopia aethiopica (Uda) is a popular spice used in the preparation of soups. Fifty volunteers between the ages of 18 to 30 (mean age of $22.58 \pm 12.75$ ) years were used for this research. They were given $20 \mathrm{ml}$ $(1.16 \mathrm{~g} / \mathrm{ml})$ of Xylopia aethiopica (X. aethiopica) extract. The baseline and induced intraocular pressure (IOP) of the volunteers were measured at 30 minutes interval after the ingestion of $X$. aethiopica until the IOP approximated the baseline value. The result showed an initial $1.26 \%$ increase in IOP at 30 mins post ingestion of $X$. aethiopica which started reducing from 60mins with a maximum reduction of $2.60 \%$ at $90 \mathrm{mins}$. The test for significance using Z-test showed the cumulative effect to be statistically significant at $95 \%$ confidence interval $(\mathrm{P}>0.05)$. The effects were transient as the induced mean IOP approximates the baseline IOP after 90 minutes of ingestion.
\end{abstract}

KEYWORDS: Xylopia aethiopica, Intraocular pressure, Ethno-medicine, Saponin, Anonecaine.

\section{Received11/12/09}

Accepted15/02/10

\section{INTRODUCTION}

Every food substance consumed by humans has either a therapeutic, nutritional or toxic effect on the body. These food substances when got in their crude form can be of immense help in the curing of some ailments. Plants as well have been used for therapeutic purposes and their uses are as old as the history of man. In the past decades, pharmacologists and organic chemists have synthesized a large number of interesting chemical substances from medicinal plants, which have been of great help in the practice of Optometry and Medicine; example is Belladonna plant from which atropine is derived.

Xylopia aethiopica (X. aethiopica) commonly known as "African guinea pepper" or "Ethiopian pepper" is wide spread in tropical Africa, Zambia, Mozambique and Angola ${ }^{1}$. In Nigeria, it is found all over the lowland rain forest and most fringe forest in the Savanna zones of Nigeria. Negro pepper as it is also known has been used as a pepper substitute in Europe and India 2 .

$X$. aethiopica is common in ethno-medicine in West Africa. This is due to its preservative effect, the fruit extract has been shown to be active as antimicrobial agent against gram positive and gram negative bacteria, though it has not been shown to be effective against Escherichia Coli ${ }^{3} . X$. aethiopica has anti-spirochoectal properties so that it works both as a preventive measure and in treatment of primary, secondary and tertiary stages of syphilis ${ }^{4}$. X. aethiopica has been used for treating rheumatism and arthritis as well as other inflammatory conditions. Numerous research studies have confirmed the spice's antiinflammatory and antipyretic (fever reducing) properties ${ }^{2,3}$. Indian researchers reported antiarthritic and anti-inflammatory actions of one of the compounds of X. aethiopica called nimbidin ${ }^{5}$.

The seeds are mainly used by traditional medicine healers and can also serve as an alternative to pepper ${ }^{6}$. Medical uses of the plants are: as a carminative, as cough remedy and as a post partum tonic and lactation aid. Other uses include treatment for stomach ache, bronchitis, biliousness and dysentery ${ }^{6}$. It has also been reported to be used as a flavour in palm wine. The back of $X$. aethiopica tree when steeped in palm wine is given for attacks of asthma and rheumatism ${ }^{7}$.

It is widely accepted that fruits and vegetables have many healthful properties. There are considerable amount of epidemiological evidences revealing an association between those who have a diet rich in fresh fruits and vegetables and a decreased risk of cardiovascular diseases and certain forms of cancer ${ }^{8,9}$. The constituent of these fruits and vegetables that contribute to these protective effects are phytochemicals, vitamins and minerals ${ }^{10}$. Naturally occurring phytochemicals like flavonoids are potentially 
anti-allergic, anti-carcinogenic, antiviral and antioxidant agents ${ }^{11}$. Phytochemicals as antioxidants play vital roles in human health ${ }^{9,12} . X$. aethiopica has been found to contain some phytochemicals which exhibit a wide range of biological effects as a consequence of their antioxidant properties ${ }^{11}$.

The chemical components of $\mathrm{X}$. aethiopica have been helpful in the avoidance and treatment of cancerous tumors. Researchers in India, Europe and Japan have found that polysaccharides and limonoids found in $X$. aethiopica reduce tumors and cancers ${ }^{13-15}$.

Flavonoids represent the most common and widely distributed of plant phenolics found in $X$. aethiopica. Flavonoids prevents oxidative cell damage, have strong anti-cancer activity and protects against all stages of carcinogensis ${ }^{8,9}$. As antioxidants, flavonoids from $X$. aethiopica provide anti-inflammatory action ${ }^{16,17}$. Anonecaine an alkaloids constituent of $X$. aethiopica is known to have anti-pyretic effect ${ }^{18}$. Saponins another phytochemical constituent of $X$. aethiopica have wide range of biological properties; they are used to recover homeostasis, have anti-inflammatory and anti-cancer actions ${ }^{19,20}$.

The normal IOP varies between $10 \mathrm{mmHg}$ $21 \mathrm{mmHg}$ (Mean $16 \mathrm{mmHg})^{21}$. Although there is no absolute cutoff point, $21 \mathrm{mmHg}$ is considered the upper limit of normal, and levels above this are viewed with suspicion. However in some patients, glaucomatous damage occurs with IOP less than $21 \mathrm{mmHg}$, whereas others remain unscathed, at least in a short term with IOP up to $30 \mathrm{mmHg}^{21}$.

Fluctuations in IOP occur with time of the day, heartbeat, blood pressure level and respiration ${ }^{21}$. The pattern of diurnal curves of IOP varies in the normal and glaucomatous eye, with a tendency towards increased IOP in the morning and lower IOP in the afternoon and evening. Normal eyes have a smaller diurnal fluctuation $(4 \mathrm{mmHg})$ than glaucomatous eyes in which the fluctuation may be $10 \mathrm{mmHg}$ or more ${ }^{21}$.

Since $X$. aethiopica is widely used in traditional medical practice, as spice in foods and as a preservative in drugs, there may be some effects on the general body physiology, in which the ocular functions may equally be affected. The eye care practitioners should therefore have a working knowledge of the effect of $X$. aethiopica on the ocular system.

\section{RESEARCH METHODOLOGY}

This study was carried out in the Optometry clinic of Abia State University, Uturu because of convenience of the research volunteers and the availability of research instruments and materials needed. The research was designed as a prospective and clinically based one. The volunteers used were students of Abia State University within the age limit of 18-30 (mean age of $22.58 \pm 12.75$ ) years. These volunteers passed the inclusion criteria of being emmetropic, free of any ocular or debilitating systemic disease, not under any medication and not smokers or alcoholics.

Fresh $X$. aethiopica fruits were purchased from Eke Okigwe market in Imo State, Nigeria and certified good for human consumption by a renowned botanist in the Department of Botany of the University. $X$. aethiopica extract was obtained through the batch method ${ }^{22}$, using water as the extracting solvent. The carpels of X. aethiopica were removed from their strands, washed and dried in the sun after which, 50g was measured out and ground with a grinding machine. The paste was soaked in $120 \mathrm{ml}$ of distilled water for 24 hours, after which it was filtered out using a white cotton gauge. The quantity of fluid extracted was measured. The solid filtrate was dried and weighed; the value was subtracted from the $50 \mathrm{~g}$ original value. The balance gave the quantity of $X$. aethiopica in the solution. The value obtained after extraction was approximately $43 \mathrm{~g}$ showing a balance of $7 \mathrm{~g}$ in solution of $120 \mathrm{ml}$. The concentration of $X$. aethiopica extract was $58.30 \mathrm{mg} / \mathrm{ml}$. The extract was sterilized using an autoclave.

Baseline IOP was measured before $20 \mathrm{ml}$ of $X$. aethiopica stock extract $(58.30 \mathrm{mg} / \mathrm{ml}$ concentration) was given to each subject to drink and the IOP was measured 30minutes after intake and subsequently at intervals of 30minutes until IOP returned to baseline. There are no chemokinetic studies available to the best of the researchers' knowledge but the rigor effects of ingesting the extract within few minutes post ingestion showed an instant absorption. This informed the choice of 30mins for monitoring of induced effects. All the IOP measurements were taken between $10.00 \mathrm{am}$ and $1.00 \mathrm{pm}$ to take into consideration the diurnal nature of IOP. Each measurement was repeated 3times and the average used. Data collected was tabulated and analyzed using Z-statistics. 


\section{RESULTS}

The result in table 1 showed a sharp increase in IOP within 30minutes post ingestion of $X$. aethiopica extract (from $21.81 \mathrm{mmHg}$ to $22.09 \mathrm{mmHg}$ ). After which, there was a reduction in IOP from $22.09 \mathrm{mmHg}$ to $21.83 \mathrm{mmHg}$ at 60 minutes post ingestion and further reduction below baseline IOP at 90minutes (from $21.83 \mathrm{mmHg}$ to $21.24 \mathrm{mmHg}$ ). The mean induced change in IOP was found to be $0.28 \mathrm{mmHg}$, $0.02 \mathrm{mmHg}$ and $-0.57 \mathrm{mmHg}$ with percentage change of $1.26 \%, 0.09 \%$ and $2.60 \%$ at $30 \mathrm{mins}$, $60 \mathrm{mins}$ and $90 \mathrm{mins}$ respectively post ingestion of $X$. aethiopica. Z-statistics showed the cumulative effect of $X$. aethiopica to be statistically significant $\left(\mathrm{P}>0.05 ; \mathrm{Z}_{\text {cal }}= \pm 0.83\right)$. The effect of Uda extract was found to be transient and not sustained.

It is important to point out here, though not within the scope of this study, that the initial and spontaneous reaction noticed upon ingestion of $X$. aethiopica was reflex tearing. which are antioxidants thus playing a vital role in therapies.

Also it has been shown from recent studies that anonecaine one of the constituents of Xylopia aethiopica has morphine like activity and that morphine acts through opion receptor in the eye, these receptors alpha $(\alpha)$ and kappa $(\mathrm{K})$ stimulates the parasympathetic system. Opiod receptors have different actions in the autonomic nervous system that is; it has both an agonist and antagonist effect ${ }^{26}$. It stimulates the oculomotor nerve center, which could result in the increase in accommodation thereby constricting the ciliary process and opening the canal of Schlemn ${ }^{27}$. Moreover, the phytochemical constituents of $X$. aethiopica like limonoids, nimbidin and tannins have been found to have central nervous system depressing effect, hence a parasympathetic effect that aids in IOP reduction ${ }^{28-32}$. According to Igwe et $\mathrm{al}^{33}$, the aqueous extract of $X$. aethiopica was neither miotic nor mydriatic.

Table 1:Mean change in IOP after intake of $20 \mathrm{ml}$ of $58.30 \mathrm{mg} / \mathrm{ml}$ of Xylopia Aethiopica Extract (Baseline IOP was $21.81 \mathrm{mmHg}$ ).

\begin{tabular}{llll}
\hline $\begin{array}{l}\text { Time interval } \\
(\text { Minutes })\end{array}$ & $\begin{array}{l}\text { Mean induced IOP } \\
(\mathbf{m m H g})\end{array}$ & $\begin{array}{l}\text { Mean change in IOP } \\
(\mathbf{m m H g})\end{array}$ & $\begin{array}{l}\text { \% change in IOP } \\
(\boldsymbol{\%})\end{array}$ \\
\hline 30 & 22.09 & 0.28 & 1.26 \\
60 & 21.83 & 0.02 & 0.09 \\
90 & 21.24 & -0.57 & 2.60 \\
\hline
\end{tabular}

\section{DISCUSSION}

Drinking of $20 \mathrm{ml}$ of $58.30 \mathrm{mg} / \mathrm{ml}$ of $\mathrm{X}$. aethiopica stock extract was found to induce a $1.26 \%$ increase in IOP after 30mins, followed by a $0.09 \%$ reduction at $60 \mathrm{mins}$ and $2.60 \%$ further reduction at $90 \mathrm{mins}$. The increase in IOP could be as a result of saponin which Lawal et $\mathrm{al}^{23}$ found to be abundant in X. aethiopica. Saponin has been found to increase the norepinephrine and dopamine content of central nervous system (CNS) and also to have an anti-fatigue effect and excitatory effect on the $\mathrm{CNS}^{24-26}$. This effect of saponin is sympathetic in origin and production of aqueous humor is through the stimulation of the beta receptors of the sympathetic autonomic nervous system.

The reduction effect on IOP of X. aethiopica might be as a result of its constituents like flavonoids and anonecaine. According to Agoha ${ }^{6}$, $\mathrm{X}$. aethiopica is known to contain flavonoids,
The immediate and spontaneous tearing of the volunteers upon ingestion of the stock extract showed a reflex tearing effect which is parasympathetic in origin, confirming the parasympathetic characteristics of $X$. aethiopica constituents $^{34}$.

Although the effect of Xylopia aethiopica on IOP was transient, it could affect optometric findings and analysis, it could also affect tests like tear film break up time and slit lamp biomicroscopy because Xylopia intake would cause stimulation of local axon reflex resulting in tearing. There is need to probe the social history of patients with regards to what was ingested before optometric examination.

Researches are recommended for the chemokinetic analysis of $X$. aethiopica to help in the understanding of both the systemic and ocular effects. 


\section{RE F E R E N C E S}

1. Puri S.G. and Talata O, (1978): Paper presented in A Symposium on Recent Advances in the Development, Production and Utilization of Medicinal and Aromatic plants in India: A survey of some plants used in Native Medicine of West Africa of interest to India; p. 35.

2. Sofowara, E. A. (1978): Medical Plants and traditional medicine in Africa. The pitman Press, Bath, Avon, pp 314-8.

3. Iwu, M. (1993): Handbook of Africa Medical plant. CRC Press, pp 435.

4. Mitra, C. R. and Misra, P. S. (1967): Amino acids of processed Seed meal proteins. J. Agric. Food Chem, 15 (4):697700.

5. Pillai, N. R. and Santhakumari, G. (1981): Medicinal, Culinary and Aromatic Plants in the North East. Planta Medica, 43:59-63.

6. Agoha, R.C. (1974): Medicinal Plant of Nigeria; Offset-Happen, Netherlands, pp. 86.

7. Smith, G. M., Clegg, C. K. and Grivetti, L. (1996): Mineral values of Selected Plant Foods Common to Southern Burkina Faso and to Niamey; Niger. Int. J. Food Sci. Nutri, 47:4153.

8. Salah, N., Miller, N. J., Paganga, G., Tijburg, L., Bolwell, G. P. and Riceevans, C. (1995):Polyphenolic Flavanols as Scavengers of Aqueous Phase Radicals and as ChainBreaking Antioxidants. Arch. Biochem. Biophysics, 322(2):339-46.

9. Del-Rio, A., Obdulio, B. G., Castillo, J. Main, F.R. and Ortuno, A. (1997): Uses and properties of Citrus flavonoids. J. Agric food Chem. 45:4505-15.

10. Okwu D.E. (2003): The potential of ocimum gratissimum, pergturia extersa and tetrapleura tetraptera as spice and flavoring agent. Nig. Agric. J, 34: 45148.

11. Close, D. C. and McArthur, C. (2002): Rethinking the role of many plant phenolics protection from photo damage. J. Plant Med, 99:166-72.

12. Eleangovan, V., Sekar, N., Gorindasamy, S. (1994): Chemo preventive potential of dietary bioflavoniods against 20 methyl cholanthren induce tumor genesis. Cancer Letters, 87:107 13.

13. Cai, Q. (1997): Dietary flavonoids, quercetin, luteolin and genistein, reduce oxidative DNA damage and lipid peroxidation and quench free radicals. Cancer Letters, 119(1): 99-107.

14. Hartwell, J. L. (1984): Plants Used Against Cancer: A Survey (Bioactive Plants, Vol 2). Quarterman Publications Inc, pp710.

15. Graham, J. G., Quinn, D. S., Fabricant, D. S. and Farnsworth, N. R. (2000): Plants used against cancer an extension of the work of Jonathan Hartwell. J. Ethnopharmacol. 73(3): 347-77.

16. Okwu, D. E. (2001): Improving the nutritive value of cassava tapioca meal with local spices. J. Nutraseutica Functional Med. Food 3:43-51.

17. Herthorg, M. G. L.; Feskeens, E. J. M; Hokum, C. H. and Katan, A. (1993): Dietary antioxdant flavoniods and risk of coronary heart disease: J. De Zutphen elderly study. Lancet, 342:1007 11.

18. Clarence, T. V. (1980): Volatile oils in Remington's Pharmaceutical sciences. $17^{\text {th }}$ Edn. Merck Publishing Company, Easton Pennsylvania, pp. 834-56.

19. Sparg, S. G., Light, M. E. and van Staden, J. (2004): Biological activities and distribution of plant saponins. J. Ethnopharmacol, 94 (2-3): 219-43.

20. Shoji, S. (2001): Chemistry and cancer presenting activities of Ginseng Saponins and some related triterpenoid compounds. J. Korean Med. Sci, 16(suppl): S28-37.

21. Kanski, J. J. (1994): Clinical OphthalmologyA Systematic Approach. $3^{\text {rd }}$ Edn. ButterworthHeinemann, England, 514pp.

22. Ijeh, I. I., Omodamiro, O. D. and Nwanna, I. J. (2005): Antimicrobial effects of aqueous extract and ethanolic fractions of two spices, Ocimum gratissimum and Xylopia aethiopica. Afri. J. Biotechnol, 4(9):953-6.

23. Lawal, I. O., Igboanugo, A. B. I., Osikarbor, B., Duyilemi, O.P., Adesoga,A.A. and Adeyanju, B. A. (2010): Evaluation of plant-based nontimber forest products (ntfps) as potential 
bioactive drug in South-western Nigeria. J. Clin. Med. Res, 3 (4): 061-6.

24. Kim, Y. C., Lee, J. H., Kim, M. S. and Lee, N. G. (1985): Effect of the saponin fraction of Panax ginseng on catecholamines in mouse brain. Arch. Pharmacal Res, 8(1): 45-8.

25. Tachikawa, E., Kudo, K., Kashimoto, T. and Takahashi, E. (1997): Effects of ginseng saponins on receptor stimulation-responses. Nippon Yakurigaku Zasshi, 110 (Suppl 1): 126-31.

26. Tachikawa, E., Kudo, K., Harada, K., Kashimoto, T., Miyate, Y., Kakizaki, A. and Takahashi, E (1999): Effects of ginseng saponins on responses induced by various receptor stimuli. Eur. J. Pharmacol, 12; 369(1):23-32.

27. Katzung, B. G. (2006): Basic and Clinical Pharmacology. 10 ${ }^{\text {th }}$ Edn. McGraw-Hill Publishing, 1179pp.

28. Kausik, B., Chattopadhyay, I., Banerjee, R. K. and Bandyopadhyay, U. (2002): Biological activities and medicinal properties of Neem (Azadirachta indica). Curr. Sci, 82(11): 1336-45.

29. Danjuma, N. M., Abdu-Aguye, I., Anuka, J.A., Hussaini, I. M., Zezi, A. U., Yaro, A. H., Maiha,
B. B. and Dabo, I. (2009): Central Nervous System Depressant Effect of the Hydroalcoholic Extracts of Leaves, Stem and Root Barks of Randia Nilotica Stapf. (Rubiaceae). Eur. J. Scientific Res, .25(3):35361.

30. Suárez, A., Ulate, G. and Ciccio, J. (1997): Cardiovascular effects of ethanolic and aqueous extracts of Pimenta dioica in SpragueDawley rats. J. Ethnopharma, 55(2): 107-11.

31. Sebastián, P. F., Cristina, W., Leonardo, M. L., Renee, E. G., Graham, A. R. J., Alejandro, C. P. and Mariel, M. (2006): Central nervous system depressant action of flavonoid glycosides. Eur. J. Pharma, 539(2006): 16876.

32. Pillai, N. R. and Santhakumari, G. (1984): Some pharmacological actions of 'nimbidin' a bitter principle of Azadirachta indica A Juss (neem). Ancient Sci. Life, 4(2): 88-95.

33. Igwe, S. A., Afonne, J. C. and Ghasi, S. I. (2003): Ocular dynamics of systemic aqueous extractsof xylopia aethiopica (African guinea pepper) seeds on visually active volunteers. J. Ethnopharmacol., 88(2-3): 139-42.

34. Davson, H. (1980): Physiology of the Eye. $4^{\text {th }}$ Edn. Churchill-Livingstone, Edinburgh, London, pp644. 